\title{
Rising incidence of chancroid in Rotterdam Epidemiological, clinical, diagnostic, and therapeutic aspects
}

\author{
K. C. NAYYAR, E. STOLZ, AND M. F. MICHEL \\ From the Departments of Dermatovenereology and Clinical Microbiology, Erasmus University, \\ Rotterdam, Holland
}

SUMMARY The incidence of chancroid in Rotterdam has increased by more than five-fold during 1977-78. In a retrospective study of 53 patients with chancroid seen at this clinic during this period, the results of smears were positive in $82 \%$ and of cultures in $84 \%$ (of those for whom cultures had been performed). Symptoms were generally mild. Treatment with co-trimoxazole was highly effective clinically, as confirmed by in-vitro sensitivity studies.

\section{Introduction}

Chancroid is usually considered to be a venereal disease which is prevalent mostly in tropical and subtropical countries. In the venereal disease clinic at University Hospital in Rotterdam, we previously used to diagnose chancroid in less than five patients a year until 1977. Using the same diagnostic techniques, we have observed a sudden increase in the incidence of chancroid in Rotterdam since 1977. For this reason, we have recorded retrospective data on 53 patients with chancroid (27 attending the clinic in 1977 and 26 in 1978).

\section{Patients and methods}

All records of patients with genital ulcers or inguinal bubos or both seen at this clinic in 1977 and 1978 were analysed. In addition to routine clinical examination, bacteriological investigations for the diagnosis of urethral gonorrhoea, using the method described by Stolz et al. (1974), and of trichomoniasis, using trichomonas medium RCLG (Ringer cysteine liver glucose containing penicillin G 1 megaunit/100 ml, streptomycin $1 \mathrm{~g} / 100 \mathrm{ml}$, and nystatin $50000 \mathrm{u} / 100 \mathrm{ml}$ ) were carried out, as were serological tests and darkfield examination for syphilis. Samples were taken from the ulcers for culture for gonococci, trichomonads, and yeasts. Scrapings from the bases and the walls of the ulcers were smeared on slides and examined microscopically

Address for reprints: $\operatorname{Dr} \mathrm{K}$. C. Nayyar, Department of Dermatovenereology, Faculty of Medicine, Erasmus University, PO Box 1738, Rotterdam, Holland

Received for publication 28 March 1979 for micro-organisms after being stained with Gram and Giemsa stains; cultures for herpes simplex virus and bacteria were performed for every patient.

Cultures for Haemophilus ducreyi were carried out using $25 \%$ fresh defibrinated rabbit blood in agar incubated for 48 hours in $10 \% \mathrm{CO}_{2}$ at $34^{\circ} \mathrm{C}$. The organisms were identified by their typical morphology in Gram-stained and Giemsa-stained smears from suspect colonies, by their $\mathrm{CO}_{2}$ requirement, and by the occurrence of haemolysis.

Co-trimoxazole sensitivity tests were carried out for 20 strains of $\boldsymbol{H}$. ducreyi by the disc diffusion method using impregnated discs; these indicated a minimum inhibitory concentration (MIC) of 25 $\mu \mathrm{g} / \mathrm{ml}$ with an inhibition zone of $28 \mathrm{~mm}$.

During 1977 and 1978, 673 men and 23 women with genital ulcers were examined at our clinic. The diagnosis of chancroid, based on a positive smear result or positive culture result or both, was made in $50(77 \%)$ men and in three (13\%) women.

The first six patients were treated with kanamycin $1 \mathrm{~g}$ i.m. daily for five days. The following three patients were treated with tetracycline hydrochloride $2 \mathrm{~g}$ orally daily for 10 days. Thirty-one patients were treated with co-trimoxazole two tablets twice daily and 13 patients were treated with co-trimoxazole three tablets twice daily (each tablet containing $400 \mathrm{mg}$ sulphamethoxazole and $80 \mathrm{mg}$ trimethoprim) for 10-14 days consecutively.

\section{Results}

AGE AND NATIONALITY

The mean age of the 53 patients with chancroid was 30.4 years (range 19-53). The nationalities of the patients are given in Table 1. 
Table 1 Nationalities of 53 patients with chancroid

\begin{tabular}{lrll}
\hline Nationality & No. & Nationality & No. \\
\hline West European & \multicolumn{3}{l}{ Middle-Eastern } \\
$\begin{array}{l}\text { Dutch } \\
\text { Portuguese }\end{array}$ & 16 & Turkish & 6 \\
$\begin{array}{l}\text { Spanish } \\
\text { French }\end{array}$ & 3 & African & \\
Belgian & 1 & Moroccan & 5 \\
Danish & 1 & Asian & \\
British & 1 & Indian & 1 \\
German & 1 & Pakistani & 1 \\
Finnish & 1 & Ceylonese & 1 \\
Polish & 1 & Thai & 1 \\
Yugoslavian & 1 & Total & 4 \\
Total & 35 & South American & \\
Unknown & 2 & Chilean & 1 \\
\hline
\end{tabular}

\section{OCCUPATION}

Twenty-four patients were sailors, four factory workers, three businessmen, three prostitutes, and two civil servants; four were unemployed and in 13 the occupation was unknown.

\section{COUNTRY OF ACQUISITION}

The countries where the infection was probably acquired, based on the patient's history, are shown in Table 2. Prostitutes were the probable source of infection in $48(89 \%)$ patients whereas friends or acquaintances infected five (11\%) patients.

Table 2 Probable country of acquisition of chancroid

\begin{tabular}{|c|c|c|c|}
\hline Country & $\begin{array}{l}\text { No. of } \\
\text { patients }\end{array}$ & Country & $\begin{array}{l}\text { No. of } \\
\text { patients }\end{array}$ \\
\hline \multirow{7}{*}{$\begin{array}{c}\text { Europe } \\
\text { Holland } \\
\text { Portugal } \\
\text { Finland } \\
\text { Belgium } \\
\text { Spain } \\
\text { Greece }\end{array}$} & \multicolumn{2}{|r|}{ Africa } & \\
\hline & 15 & Morocco & 5 \\
\hline & 7 & Nigeria & 3 \\
\hline & 1 & South Africa & 1 \\
\hline & 1 & Total & 9 \\
\hline & 1 & & \\
\hline & 1 & Asia & \\
\hline Total & 26 & India & 2 \\
\hline South America & & $\begin{array}{l}\text { Bangladesh } \\
\text { Nepal }\end{array}$ & $\begin{array}{l}2 \\
1\end{array}$ \\
\hline Chile & 1 & Thailand & $\begin{array}{l}1 \\
6\end{array}$ \\
\hline Middle East & & & \\
\hline Turkey & 4 & Unknown & 7 \\
\hline
\end{tabular}

INCUBATION PERIOD

In 22 patients, for whom a definite history was available, the incubation period varied from two days to three weeks.

\section{LESIONS}

Ulcers occurred on the penis in 48 patients, in the groin and on the penis in one, in the perianal region in one, and on the vulva in three. Twenty-six patients had single penile lesions whereas 23 had multiple lesions. In 29 patients lymph nodes were enlarged. The lesions on the vulva occurred singly without enlargement of the lymph nodes. In general, the symptoms were mild.

\section{CULTURE AND MICROSCOPY}

Results of Gram-stained and Giemsa-stained smears and cultures for the detection of $\boldsymbol{H}$. ducreyi are given in Table 3. In all 20 strains of $\boldsymbol{H}$. ducreyi, for which the sensitivity for co-trimoxazole was determined, a $\mathrm{MIC}<25 \mu \mathrm{g} / \mathrm{ml}$ was found.

Table 3 Results of Gram-stained and Giemsa-stained smears and cultures for $\mathrm{H}$. ducreyii

\begin{tabular}{lllll}
\hline & & \multicolumn{3}{l}{ Results } \\
\cline { 4 - 5 } $\begin{array}{l}\text { No. of } \\
\text { patients }\end{array}$ & $\begin{array}{l}\text { \% of } \\
\text { total }\end{array}$ & $\begin{array}{l}\text { \% of } \\
\text { total }\end{array}$ & Smear & Culture \\
\hline 24 & 45 & 53 & + & + \\
6 & 11 & 13 & ++ & + \\
8 & 15 & 18 & - & + \\
7 & 13 & 16 & + & - \\
8 & 15 & & + & ND \\
\hline + Positive - negative & & & \\
* Not including those patients for whom cultures were not performed \\
tDoubtful-positive \\
ND=not done
\end{tabular}

CHANCROID AND OTHER STDS

In addition to chancroid, two patients also had early latent syphilis, one primary syphilis and genital warts, one gonorrhoea, one trichomoniasis, one candidosis, one herpes simplex virus infection, and one gonorrhoea, trichomoniasis, and candidosis.

\section{TREATMENT}

The six patients treated with kanamycin were cured within one week whereas the three patients treated with tetracycline were cured within two weeks. Of the 44 patients treated with co-trimoxazole, 18 did not return for follow up. Among those who did return, there were no treatment failures and the time the ulcers took to heal varied from one to two weeks. None of the patients who attended after treatment complained of side effects.

\section{Discussion}

The finding of 53 cases of chancroid in this clinic in 1977 and in 1978, compared with less than five cases a year during the previous years, certainly shows a marked increase in its incidence in Rotterdam. In recent years a sudden increase has been reported by several workers in other countries. Morel (1974) observed an epidemic of chancroid in Paris during 1973. Lüders et al. (1975) reported a similar increase in West Germany. In the Netherlands, an increase in incidence has been reported by Baart de la Faille $e t$ al. (1977) and recently Murat et al. (1978) reported an 
epidemic in Istanbul, Turkey. Most of our patients were either Dutch, Portuguese, Turkish, or Moroccan. Of the six Turks, four had been infected in Turkey. This finding may perhaps correlate with the recently reported epidemic in Turkey (Murat et al., 1978). Of the Portuguese and Moroccans, only two were infected in Rotterdam whereas the remaining 11 had been infected in their own countries. Two Turks, two Portuguese, one Greek, one Spaniard, and nine Dutch, including the three prostitutes, had a history of sexual contact in the same part of Rotterdam, where prostitutes are frequently visited by immigrant workers. Before 1977 , no patients with chancroid, infected either in Rotterdam or in Holland, were seen in our outpatient department. The possibility, therefore, that the infection is being imported from outside the Netherlands, must be considered. Prostitutes constitute a large reservoir of infection (Gaisin and Heaton, 1975); $89 \%$ of our patients acquired the infection from prostitutes, and all three women in our study were prostitutes.

In our study the smears of $82 \%$ of patients gave a positive result for $\boldsymbol{H}$. ducreyi. This finding agrees with an earlier report by Reymen (1951), who also found that smears gave a positive result in $50-83 \%$ of cases. Had we only examined smears, we might have missed the diagnosis in eight $(\mathbf{1 8 \%})$ patients. The fact that cultures gave negative results in $16 \%$ of patients with a positive smear result is more difficult to explain, but the reason may be that some smears gave a false-positive result and that the culture method was still not perfect.

$H$. ducreyi is resistant to sulphonamides (Marmer, 1972; Baart de la Faille et al., 1977). Alternative drugs used by some workers are kanamycin (Marmer, 1972), gentamicin (Lüders et al., 1975), and tetracyline (Murat et al., 1978). Kanamycin and gentamicin, however, are potentially toxic drugs and, moreover, need to be given parenterally. Tetracycline is treponemacidal and can therefore mask syphilis. Our studies showed that all the strains of $H$. ducreyi tested were sensitive to co-trimoxazole, and all patients responded well clinically.

Similar observations have also been reported by de Sablet and Puissant (1974) and by Morel (1974). In view of the disadvantages of kanamycin, gentamicin, and tetracycline and of our clinical experience with co-trimoxazole, the latter appears to be the drug of choice in the treatment of chancroid.

We gratefully acknowledge the technical assistance of Mrs G. E. Bosscher-Koetsier, Mrs M. P. L. de Jonge-Suy, Mrs S. de Weerdt-van Ameyden, and $\mathrm{Mr}$ E. O’Niel.

\section{References}

Baart de la Faille, H., Deenstra van Leeuwen, M. M., Wagenvoort, J. H. T., de Gerr, D. B., de Groot, L. J., and Mouton, R. P. (1977). Toenemende frequentie van ulcus molle. Nederlands Tijdschrift voor Geneeskunde, 121, 929-932.

de Sablet, M. and Puissant, A. (1974). Le chancre mou: sa réapparition à Paris, ses complications, son traîtement. Progrès Médical, 102, 343-348.

Gaisin, A. and Heaton, C. L. (1975). Chancroid: alias the soft chancre. International Journal of Dermatology, 14, 188-197.

Lüders, G., Braun, J., Pietzeker, F., and Schülle, D. (1975). Neue therapeutische gesichtspunkte beim ulcus molle. Der Hautarzt, 26, 35-40.

Marmer, J. L. (1972). The management of resistant chancroid in Vietnam. Journal of Urology, 107, 807-808.

Morel, P. (1974). Le chancre mou. Nouvelle Presse Médicale, 3, 214-216.

Murat, A., Oke, N., and Baransii, O. (1978). Ulcus molleEpidemie in der Türkei. Der Hautarzt, 29, 583-585.

Reymen, F. (1951). Studies on the bacteriology of Haemophilus ducreyi with special reference to the diagnosis of chancroid. Danish Science Press: Copenhagen. 


\section{Book reviews}

Sexually Transmitted Diseases: The Facts. David Barlow, 1979. Pp 140, 8 figs. Oxford University Press, Oxford (£4.50).

This book on sexually transmitted diseases will be of great interest to a wide range of readers, including health educators and those in other health professions. It provides current factual knowledge on the main venereal diseases and on a variety of infections and infestations transmitted sexually.

Several sections of the book have special appeal. In the chapter on "Sexual anatomy and function" there are excellent illustrations with a readable text, including an important section on variations in sexual behaviour. In this and in other chapters dealing with specific infections, reference is made to homosexuality and the prevalence of sexually transmitted diseases in this group.

The chapter on "History and development of a service" provides educationalists with an excellent basis for inclusion in any programme on this particular aspect of human relationships. This section concludes with the evolution of clinical services in this country, which are recognised to be the best in the world. The author helpfully provides a complete list of clinics in the United Kingdom at the very end of the book.

The section on tropical diseases is an important addition to any book on sexually transmitted diseases, as it contains valuable information on the increasing minority of ethnic grouping in urban areas of this country and on the Continent.

Chapters on each of the infections contain a wealth of information on signs, symptoms, treatment, and incidence of the respective infections. The lay reader may well need to refer to the glossary of clinical terms provided by the author at the back of the book.

Details are given on the location of clinics, their staffing, confidentiality, and treatment, which, I am sure, will help to overcome the stigma of attending a hospital for treatment of diseases of a sexual nature. This will be useful for young people, who are considered to be a high-risk group.

The author finally discusses control and various factors which he considers will help to curb the worldwide increase in these diseases.

The amusing cartoons by Dickinson provide a good counter-balance to the superb medical illustrations in the book.

I consider that this book will be a welcome addition to libraries in schools, colleges for further education, teaching hospitals, as well as in health education units, health centres, and medical group practices. It may well be useful for copies to be sent to the Gay Liberation Movement and to the Campaign for Homosexual Equality.
Boswell's Clap and Other Essays: Medical Analyses of Literary Men's Afflictions. William B Ober, 1979. Pp 291, 10 figs. Southern Illinois University Press, Carbondale and Edwardsville, Feffer and Simons, London and Amsterdam (US\$17.50).

It is a pity that this title has been chosen for such a recondite collection of superb essays, attracting the voyeur in many a physician browsing in a medical bookshop. Dr W Ober, a histopathologist, has been recognised for many years as a leading American medical historian coming from the school of scholar-philosophers found on the eastern seaboard. He takes 10 literary figures or groups; Boswell, Swinbourne, D H Lawrence, John Keats and George Crabbe, Collins, Cowper and Smart, Chekhov, William Carlos Williams, the Earl of Rochester, Thomas Shadwell, and Socrates, and analyses aspects of their lives, using the skills of his specialty. In this process he makes some remarkable, but probably correct, diagnoses, often backed by psychopathological arguments. His groundwork cannot be faulted, taking into consideration literary and historical published work as well as primary sources. Venereologists will find not only the title essay illuminating but also a great deal of interest in pyschosexual pathology in at least half the other essays, notably those on Swinbourne, Keats, D H Lawrence, and the Earl of Rochester.

Ober details 19 instances of urethritis, mostly probably gonococcal in origin in Boswell's life between the age of 19 and 50, an attack of crab lice, and one of genital sores, probably not syphilitic. What seems most interesting are the psychological reasons for Boswell's repeated infections, despite-in latter years-a constant wife and his frequent visits to a succession of medical men. Not only did he consult surgeons no longer remembered but also doctors who are celebrated today:
Morgagni in Padua, Pott in London, as well as Pringle and Gregory in Edinburgh.

An early example of contact-tracing is when Boswell paid for the treatment at St Thomas's Hospital of Betsey Smith, a prostitute from whom he contracted gonorrhoea in 1785 . It is also worth remembering in these days of easy treatment the fate of Boswell, dying at 55 of uraemia, the result of acute and chronic urinary tract infection secondary to postgonococcal urethral stricture.

Michael Waugh

\section{Correction}

In the paper by Dr K C Nayyar et al on the "Rising incidence of chancroid in Rotterdam" (1979; 55:439-41) the figure in the last line of the fourth paragraph of the section on patients and methods should have been $7 \cdot 4 \%$ and not $\mathbf{7 7 \%}$. 